\title{
PELAKSANAAN PEMBERIAN KREDIT PADA PT. BANK PERKREDITAN RAKYAT LA MANGAU SEJAHTERA PARIAMAN
}

\author{
Yunita Selvia, Ratna Widayati \\ Akademi Keuangan dan Perbankan Padang \\ ratnawidayati@akbpstie.ac.id
}

\begin{abstract}
ABSTRAK
Tujuan dari penelitian ini adalah untuk mengetahui pelaksanaan pemberian kredit pada nasabah terhadap PT. BPR La Mangau Sejahtera Pariaman. Jenis penelitian ini adalah bersifat deskriptif dengan menggunakan metode analisa data kualitatif. Kesimpulan 1) Di dalam pelaksanaannya kredit yang disalurkan oleh BPR LA Mangau Sejahtera Pariaman adalah kredit yang berdasarkan tujuan penggunaannya yang terdiri kredit modal kerja (KMK), investasi dan konsumsi. Dengan tingkat bunga kredit sebesar 13\% sampai 20\% . 2) Faktor penyebab terjanjinya kredit bermasalah pada PT. BPR LA Mangau Sejahtera Pariaman adalah faktor intern, faktor ekstern, dan faktor kesulitan usaha, dan Penanganan atau mengatasi kredit bermasalah dengan Tindakan preventif, Tindakan revitalisasi dan Tindakan kuratif.
\end{abstract}

Kata Kunci: Kredit, BPR

\section{PENDAHULUAN}

Sektor perbankan telah menunjukkan peranan yang sangat penting dalam menunjang pembangunan ekonomi nasional. baik melalui fungsinya sebagai penghimpun dana dari masyarakat maupun sebagai lembaga keuangan dan menyalurkan dana-dana tersebut dalam bentuk kredit dalam rangka meningkatkan taraf hidup rakyat banyak. Investasi dan pembangunan dari suatu kegiatan usaha memerlukan adanya sumber dana untuk membiayai usaha tersebut. Kebutuhan dana secara teoritis selain dapat dipenuhi oleh sumber dana intern juga dapat diperoleh dari sumber dana ekstern.

Pada hakekatnya tugas pokok bank adalah menghimpun dana dari masyarakat dan menyalurkannya dalam bentuk kredit serta memberikan jasa-jasa lainnya. Dilihat dari fungsi utama sebuah Bank adalah sebagai lembaga yang dalam aktivitas usahanya menghimpun dan menyalurkan dana masyarakat. Salah satu cara penyaluran dana tersebut adalah melalui kebijakan kredit yang dilakukannya, 
sehingga dengan kata lain kesehatan perbankan akan sangat dipengaruhi oleh resiko kredit. Tujuan utama bank bukan semata-mata untuk mencapai keuntungan melainkan yang lebih penting adalah mempertahankan eksistensinya ditengah iklim persaingan yang demikian ketat dan menjaga reputasinya di tengah-tengah masyarakat. Unsur utama dalam penyaluran kredit yaitu kepercayaan (keyakinan) bahwa kredit yang diberikan akan benar-benar diterima pengembaliannya dimasa yang akan datang. Unsur ini harus disertakan oleh prinsip kehati-hatian yang tinggi, karena dana kredit merupakan dana simpanan nasabah yang dititipkan pada bank.

Penyaluran kredit kepada masyarakat merupakan kegiatan utama bank yang tidak hanya memberi manfaat bagi bank, nasabah penerima kredit tetapi juga bagi pemerintah. Salah satu manfaat penting yang diperoleh bank adalah memperoleh pendapatan bunga. Bagi nasabah, kredit merupakan sumber yang dapat dimanfaatkan untuk mengembangkan dan membuka usahanya serta bagi pemerintah, penyaluran kredit dapat mendorong pertumbuhan ekonomi secara nasional. Kredit mempunyai kedudukan yang sangat istimewa, terutama pada negara-negara yang sedang berkembang. Peranan bank dalam mendukung kegiatan perekonomian cukup besar karena bank memberikan jasa dalam lalu lintas peredaran uang. Untuk memberikan kredit kepada suatu lembaga atau perorangan salah satu syaratnya adalah agunan atau jaminan. Dimana jaminan tersebut akan mengurangi resiko yang mungkin terjadi dalam setiap pemberian kredit. Piutang kredit tersebut harus dikelola dengan baik oleh bank sehingga akan mampu memberikan keuntungan bagi bank dan menjamin kelancaran pembayaran debitur. Dengan demikian kredit tersebut tidak akan masuk dalam golongan kredit bermasalah (macet) yang akan mengakibatkan kerugian bagi bank.

Sejak berlakunya Undang-Undang No.7 Tahun 1992 dan telah diperbaharui menjadi Undang-Undang No. 10 Tahun 1998 Pasal 5 Ayat 1, jenis bank yang diakui secara resmi hanya terdiri dari 2 ( dua ) jenis yaitu Bank Umum dan Bank Perkreditan Rakyat.

Bank Umum didefinisikan oleh Undang-Undang No. 10 tahun 1998 Pasal 1 Ayat 4 tentang Perbankan sebagai berikut: " Bank yang melaksanakan kegiatan usaha secara konvensional dan atau berdasarkan prinsip syariah yang dalam kegiatannya memberikan jasa dalam lalu lintas pembayaran"

Bank Perkreditan Rakyat didefenisikan oleh Undang-Undang No. 10 tahun 1998 Pasal 1 Ayat 4 tentang Perbankan sebagai berikut: "Bank Perkreditan Rakyat adalah Bank yang melaksanakan kegiatan usahanya secara konvensional atau berdasarkan prinsip syariah yang dalam kegiatannya tidak memberikan jasa dalam lalu lintas pembayaran".

Berdasarkan hal-hal tersebut, maka penulis mencoba melakukan suatu penelitian dan membahasnya dalam Tugas Akhir dengan judul "Pelaksanaan Pemberian Kredit Pada PT. BPR LA Mangau Sejahtera Pariaman”.

Sesuai dengan judul diatas, maka masalah yang dibahas dalam Tugas Akhir adalah, Bagaimana pelaksanaan pemberian kredit pada nasabah terhadap PT. BPR LA Mangau Sejahtera Pariaman. 


\section{METODE PENELITIAN}

Di dalam melakukan penelitian ini akan digunakan metode pengumpulan data dengan dua cara yaitu :

1. Studi Pustaka (Library Research)

Penelitian ini dilakukan dengan cara mempelajari buku-buku, makalahmakalah, artikel-artikel, bacaan laporan-laporan dan publikasi yang berhubungan dengan objek penelitian.

2. Studi Lapangan (Field Reseach)

Penelitian yang langsung dilakukan pada PT. Bank Perkreditan Rakyat LA Mangau Sejahtera Pariaman untuk memperoleh data yang diperlukan dan melakukan wawancara untuk mendapatan data primer.

\section{LANDASAN TEORI}

\section{Pengertian dan Jenis-jenis Kredit}

Menurut Johanes (2004 : 7) kata "kredit" berasal dari bahasa Romawi "credere" yang berarti percaya atau credo atau creditum yang berarti saya percaya. Dengan demikian dasar dari pada kredit adalah kepercayaan.

Dilihat dari sudut ekonomi, kredit diartikan sebagai penundaan pembayaran. Maksudnya pengembalian atas penerimaan uang dan / atau suatu barang tidak dilakukan bersamaan pada saat penerimaannya, akan tetapi pengembaliannya dilakukan pada masa tertentu yang akan datang.

Undang-undang perbankan nomor 10 tahun 1998 Pasal 1 Ayat 11 Kredit, Kredit adalah penyediaan uang atau tagihan yang dapat di persamakan dengan itu, berdasarkan persetujuan atau kesepakatan pinjam meminjam antara bank dengan pihak lain yang mewajibkan pihak peminjam untuk melunasi utangnya setelah jangka waktu tertentu dengan pemberian bunga, imbalan atau pembagian hasil tertentu. Kredit juga didefinisikan sebagai penyerahan atas dasar kepercayaan sejumlah uang atau barang yang dipersamakan dan wajib dikembalikan sesuai dengan syarat-syarat yang disepakati bersama.

Adapun menurut Hasibuan (2007:87) mengemukakan pengertian kredit yang lebih jelas bahwa: " Kredit adalah penyediaan uang atau tagihan yang harus dibayar kembali bersama bunganya oleh peminjam sesuai dengan perjanjian yang telah disepakati".

Selanjutnya Latumerissa (1999:45) kredit adalah : "Penyerahan sesuatu yang mempunyai nilai ekonomis pada saat sekarang ini atas dasar kepercayaan, sebagai pengganti sesuatu yang mempunyai nilai ekonomis yang sepadan dihari kemudian.

Berdasarkan pengertian diatas dapat disimpulkan bahwa suatu fungsi pokok dari kredit pada dasarnya adalah untuk pemenuhan jasa pelayanan terhadap kebutuhan masyarakat dalam rangka mendorong dan melancarkan kegiatan usaha berbagai bidang yang semua itu untuk meningkatkan taraf hidup rakyat dalam hal ini mempermudah dan mempercepat mendapatkan modal usaha. 

berikut :

Secara umum umum jenis kredit yang di salurkan oleh bank sebagai

1. Jenis Kredit Berdasarka Tujuan Penggunaanya, dibedakan dalam :

a. Kredit Modal Kerja (KMK)

Merupakan Kredit yang ditujukan untuk memberikan modal usaha seperti antara lain pembelian bahan baku atau barang yang akan diperdagangkan. Dalam hal ini BPR LA Mangau Sejahtera Pariaman menerapkan program kredit yang bersifat Diskonto.

Diskonta yaitu Pembayaran bunga dimuka, agar nasabah menjadi lebih ringan karena hanya membayar anggsuran pokok di akhir.

b. Kredit Investasi

Merupakan Kredit yang ditujukan untuk modal usaha pembelian sarana alat produksi dan atau pembelian barang modal berupa aktiva tetap atau investasi.

c. Kredit Konsumtif

Merupakan Kredit yang ditujukan untuk pembelian suatu barang yang digunakan untuk kepentingan perseorangan (pribadi). Kredit ini di BPR LA Mangau Sejahtera Pariaman menjadi paket penawaran untuk institusi atau lembaga.

2. Jenis Kredit Berdasarkan Cara Pembayaran atau Anggsuran Bunga, dibedakan dalam :

a. Kredit dengan Anggsuran Pokok dan Bunga Periodik

Merupakan Anggsuran untuk jenis pokok dan bunga dibayar atau diangsur tiap periodik yang telah ditentukan.

Misalnya Bulanan.

b. Kredit dangan Bunga Dibayar Secara Periodik dan Pokok Dibayar Pada Akhir Jatuh Tempo

c. Kredit dengan Bunga dan Pokok Dibayar Secara Periodik, namun tidak ditetapkan secara merata.

3. Jenis Kredit Berdasarkan Metode Hitungan Angsuran yang akan digunakan. Ada tiga Metode yang ditawarkan yaitu :

a. Efektif

Merupakan Anggsuran yang dibayarkan selama periode angsuran mengikuti prinsip "Time Value Of Money".

Time Value Of Money yaitu Nilai angsuran akan berpijak pada nilai uang yang berlaku pada saat ini. Tipe ini angsuran pokok pinjaman menurun dan nisbah naik.

b. Flat

Merupakan Angsuran pokok dan bunga merata untuk setiap periode.

c. Sliding

Merupakan Angsuran pokok peminjam tetap dan bunganya menurun mengikuti sisa pinjaman (outstanding).

4. Jenis Kredit Berdasarkan Jangka Waktu Pemberiannya dibedakn dalam : 
a. Kredit dengan Jangka Waktu Pendek

Merupakan kredit yang memiliki jangka waktu kurang dari satu tahun atau paling lama satu tahun dan biasanya untuk keperluan modal kerja.

b. Kredit dengan Jangka Waktu Menengah

Jangka waktu kreditnya berkisar antara satu tahun sampai tiga tahun, dan biasanya kredit ini untuk melakukan investasi

c. Kredit dengan Jangka Waktu Panjang

Merupakan kredit yang masa pengembaliannya paling lama, yaitu diatas tiga tahun atau lima tahun dan biasanya untuk keperluan investasi jangka panjang.

5. Jenis Kredit Berdasarkan Sektor Usaha yang dibiayai

a. Kredit Sektor Perdagangan

b. Kredit Sektor Industri

c. Kredit Rill

d. Leasing

BPR LA Mangau Sejahtera Pariaman, hanya menyalurkan kredit berdasarkan jenis tujuan penggunaannya yang terdiri dari kredit modal kerja (KMK), investasi dan konsumsi sedangkan pemberian kredit berdasarkan sektor ekonomi digunakan untuk keperluan pertanian, perindustrian, perdagangan, dan jasa-jasa. Tingkat bunga kredit di BPR LA Mangau Sejahtera Pariaman sebesar $13 \%$ sampai $20 \%$.

\section{Pelaksanaan Pemberian Kredit}

Manajemen Perkreditan adalah Suatu proses yang terintegrasi antara sumber-sumber - sumber dana perkreditan , alokasi dana yang dapat dijadikan perkreditan dengan melalui proses planning (perencanaan), organizing (pengorganisasian), controlling (pengadministrasian) dan actuating (pengawasan).

Dalam memberikan kredit BPR wajib mempunyai keyakinan berdasarkan analisis yang mendalam atas itikad dan kemampuan serta kesanggupan nasabah debitur untuk melunasi utangnya sesuai dengan perjanjian. Dalam memberikan kredit dan melakukan kegiatan usaha lainnya, BPR wajib menempuh cara-cara yang tidak merugikan BPR dan kepentingan nasabah yang mempercayakan dananya pada BPR. BPR wajib menyusun, memiliki dan menerapkan pedoman pedoman kredit BPR secara tertulis. Pelaksanaan kredit dilakukan berdasarkan pedoman perkreditan BPR.

Dalam memberikan kredit BPR wajib memperhatikan ketentuan tentang prinsip kehati-hatian seperti :

$>$ Kewajiban Penyediaan Modal Minimum (KPMM).

$>$ Batas Maksimum Pemberian Kredit (BMPK)

Pemberian fasilitas kredit kepada nasabah mencakup penyediaan dana berdasarkan persetujuan atau kesepakatan bersama antara pihak bank dengan nasabah untuk melunasi kewajibannya setelah jangka aktu tertentu.

Batas Maksimum Pemberian Kredit (BMPK) ada 2 yaitu :

i. BMPK untuk Pihak Terkait 
Baik sebagai satu peminjam atau kelompok peminjam ditetapkan setinggitingginya sebesar $10 \%$ (sepuluh per seratus) dari modal. BMPK untuk jumlah seluruh pihak terkait ditetapkan setinggi-tingginya sebesar 10\% (sepuluh per seratus).

ii. BMPK untuk Pihak Tidak Terkait

BMPK bagi peminjam atau kelompok peminjam yang merupakan pihak tidak terkait ditetapkan setingginya $20 \%$ (dua puluh per seratus) dari modal.

$>$ Kualitas Aktiva Produktif (KAP)

$>$ Penyisihan Penghapusan Aktiva Produktif (PPAP)

$>$ Jaminan Kredit

Kredit yang diberikan oleh BPR mengandung risiko sehingga dalam pelaksanaannya BPR harus memperhatikan asas-asas perkreditan yang sehat. Untuk mengurangi risiko tersebut, jaminan kredit merupakan faktor yang penting diperhatikan BPR. Agunan sebagai salah satu unsur pemberian kredit, maka apabila berdasarkan unsur-unsur lain telah dapadiperoleh keyakinan atas kemampuan nasabah debitur mengembalikan utangnya, agungan dapat berupa barang proyek, atau hak tagih yang dibiayai dengan kredit yang bersangkutan.

Komite Kredit adalah Suatu lembaga yang berwenang untuk memberikan persetujuan suatu permohonan fasilitas kredit nasabah. Keputusan-keputusan yang diambil komite kredit ini antara lain :

a. Memberikan persetujuan terhadap proposal yang diajukan.

b. Memberikan persetujuan dengan bersyarat atau catatan yang harus dipenuhi terlebih dahulu terhadap proposal yang diajukan.

c. Menolak proposal yang diajukan.

Dari keputusan komite tersebut maka diketahuilah fungsi dan tugas komite kredit antara lain :

a) Membahas dan mengevaluasi proposal kredit yang diajukan oleh sttaf kredit secara lebih mendetail.

b) Menyetujui atau menolak proposal kredit.

c) Membahas dan mengevaluasi masalah proposal kredit serta mengambil keputusan dan menetapkan lanngkah untuk menyelesaikan termasuk rekomendasi penghapusan kredit dan atau menyerahkan kepihak ketiga.

d) Membahas dan mengevaluasi perubahan atau pengalihan tingkat kolektibilitas.

Prosedur pemberian dan penilaian kredit oleh dunia perbankan secara umum antar BPR yang satu dengan BPR yang lain tidak jauh berbeda. Yang menjadi perbedaan mungkin hanya terletak dari bagaimana tujuan BPR tersebut, serta persyaratan yang ditetapkannya dengan pertimbangan masing-masing. Secara umum prosedur pemberian kredit oleh BPR adalah sebagai berikut :

1. Permohonan Kredit 
Calon debitur mengajukan permohonan kredit secara tertulis ke bank yang dituju. Dengan mengisi daftar isian / formulir yang telah disediakan oleh bank, dengan melampirkan :

Jika jaminan BPKB

a. Foto copy KTP suami dan istri

b. Foto copy kartu susunan keluarga

c. Foto copy STNK

d. Foto copy BPKB

e. Foto copy buku KIR (untuk roda 4 jenis angkutan)

f. Kendaraan jaminan dan data asli harus dibawa

Jika jaminan sertifikat tanah

a. Foto copy KTP suami dan istri

b. Foto copy kartu susunan keluarga

c. Foto copy sertifikat tanah

d. Bukti pembayaran pajak tanah dan bangunan (SPPT)

e. Sertifikat aslinya harus dibawa

2. Pemeriksaan Kelengkapan Administrasi

Bank meneliti surat permohonan / aplikasi kredit serta kelengkapan dan kebenaran dokumen-dokumen yang diserahkan calon debitur.

3. Analisis Kredit

Bank melakukan penelitian / menganalisa terhadap dana yang tersedia (plafond kredit) dan pribadi calon nasabah serta segala sesuatu yang disyaratkan, yang berhubungan dengan usaha calon nasabah dengan prinsip $5 \mathrm{C}$.

Dalam melakukan penilaian permohanan kredit BPR bagian marketing harus memperhatikan beberapa prinsip utama yang berkaitan dengan kondisi secara keseluruhan calon nasabah. Di dunia perbankan prinsip penilaian dikenal dengan $5 \mathrm{C}$ yaitu :

a) Character ( Kepribadian, watak )

Character adalah Penilaian terhadap karakter atau kepribadian calon peminjam dengan tujuan untuk memperkirakankemungkinan bahwa peminjam dapat memenuhi kewajibannya.

b) Capacity ( Kemampuan, kesanggupan )

Capacity adalah Penilaian secara subyektif tentang kemampuan peminjam untuk melakukan pembayaran.

Kemampuan diukur dengan catatan prestasi peminjam di masa lalu yang didukung dengan pengamatan di lapangan atas sarana usahanya seperti, toko, karyawan, alat-alat, pabrik serta metode kegiatan.

c) Capital ( Modal, kekayaan )

Capital adalah Penilaian terhadap kemampuan modal yang dimiliki oleh calon peminjam yang diukur dengan posisi perusahaan secara keseluruhan yag ditujukan oleh rasional finansial dan penekan pada komposisi modalnya.

d) Collateral ( Jaminan, agunan ) 
Collateral adalah Jaminan yang dimiliki oleh calon peminjam. Penilaian ini bertujuan untuk lebih meyakinkan bahwa jika suatu resiko kegagalan pembayaran tercapai terjadi, maka jaminan dapat dipakai sebagai pengganti dari kewajiban.

e) Condition of economy

BPR harus melihat kondisi ekonomi yang terjadi di masyarakat secara spesifik melihat adanya keterkaitan dengan jenis usaha yang dilakukan oleh calon peminjam, Hal tersebut karena kondisi eksternal berperan besar dalam proses berjalannya usaha calon peminjam. Kepatuhan terhadap hukum dan undangundang yang berlaku itu sangatlah penting. Hal ini menyangkut atas kepatuhan kreditur dan debitur dengan perjanjian yang telah disepakati bersama. Nasabah tidak pernah memiliki catatan kriminal dalam kepolisian. Nasabah juga mematuhi peraturan yang ada di bank, yaitu memenuhi persyaratan permohonan kredit dengan lengkap.

a. Tujuan penggunaan kredit.

b. Plafon, jangka waktu dan jenis kredit diajukan.

c. Masa tenggang khususnya pada kredit investasi.

d. Cara pembayaran.

e. Sumber pelunasan kredit.

f. Analisa jaminan kredit dan pengikatannya.

g. Penetapan biaya adm, divisi, komisi dan asuransi kredit.

h. Persetujuan kredit yang berbeda dalam rekomendasi, harus jelas alasannya.

4. Keputusan kredit

Setelah proses analisis tersebut sudah dilaksanakan, maka petugas kredit dapat memutuskan, apakah kredit tersebut disetujui, ditolak, dikurangi, ditambah atapun diperpanjang.

5. Apabila permohon kredit di setujui maka Bank menyuruh debitur untuk menandatangani Akad Perjanjian Kredit (APK) dan Penandatanganan APK . Jika permohon kredit tidak disetujui maka pihak bank membuat surat penolakan atas permohonan kredit kepada calon debitur yang mencantumkan alasan-alasan penolakan dan mengembalikn seluruh dokumen calon debitur yang diserahkan pada saat pengajuan kredit.

6. Setelah penandatangan kredit selesai, Pencairan kredit

a. Debitur dapat membuka rekening tabungan pada bank.

b. Debitur membuat surat kuasa kepada bank untuk melakukan pendebetan rekening.

c. Bagian Adm kredit memo pencairan kredit, bagian tabungan beserta kwitansi pencairan kredit rangkap dua, nota kredit atas pencairan kredit, nota debet untuk pembebanan biaya adm, provisi dan komisi, materai notaris dan asuransi.

d. Debitur menandatangani kwitansi pencairan kredit dihadapan petugas tabungan.

e. Kertas asli diserahkan kebagian adm kredit, lembar tembusan diserahkan kepada tembusan. 


\section{Perkembangan Usaha BPR LA Mangau Sejahtera}

Dalam kegiatan perkreditan bank, khususnya PT. BPR LA Mangau Sejahtera Pariaman memberikan kredit kepada debitur. Pengembalian ini sering disebut sesuai dengan sektor usaha debitur. Adapun kredit yang diberikan oleh PT. BPR LA Mangau Sejahtera Pariaman berdasarkan jenis tujuan penggunaannya yang digunakan untuk keperluan kredit modal kerja (KMK), investasi dan konsumsi sedangkan pemberian kredit berdasarkan sektor ekonomi digunakan untuk keperluan pertanian, perindustrian, perdagangan, dan jasa-jasa.

Perkembangan Usaha BPR LA Mangau Sejahtera Pariaman seperti asset, dana masyarakat, penyaluran kredit, dan permodalan dilihat dari beberapa tahun terakhir pada grafik sebagai berikut ini :

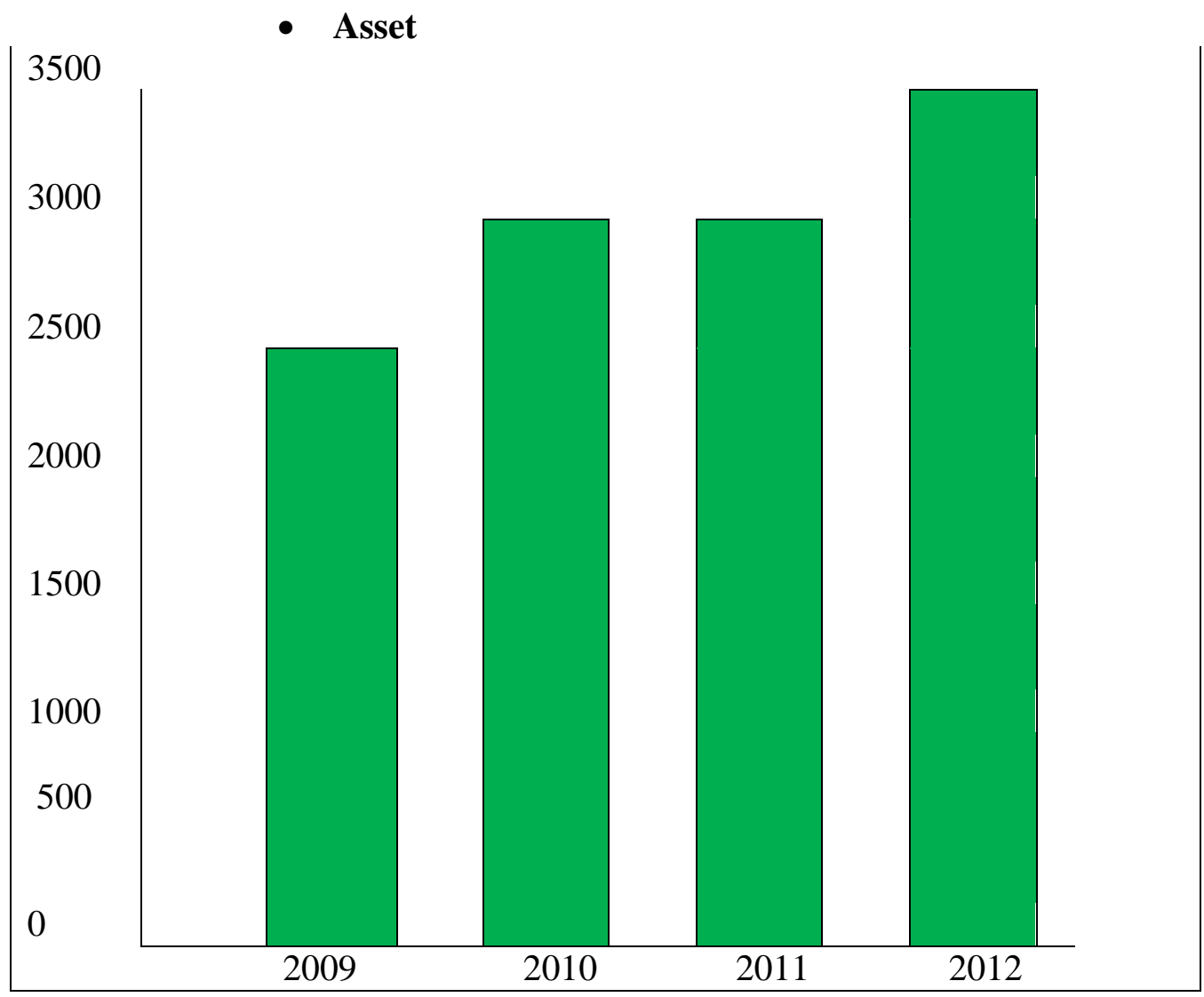

Sumber : PT. BPR LA Mangau Sejahtera Pariaman 
Asset pada Desember 2009 sebesar Rp. 2.306.000.000 meningkat menjadi Rp. 2.677.000.000 pada akhir Desember 2010, namun pada akhir Desember 2011 tahun sedikit menjadi Rp. 2.653.000.000. Pada 2012 asset meningkat menjadi Rp. 3.376.000.00

\section{- Dana Masyarakat}

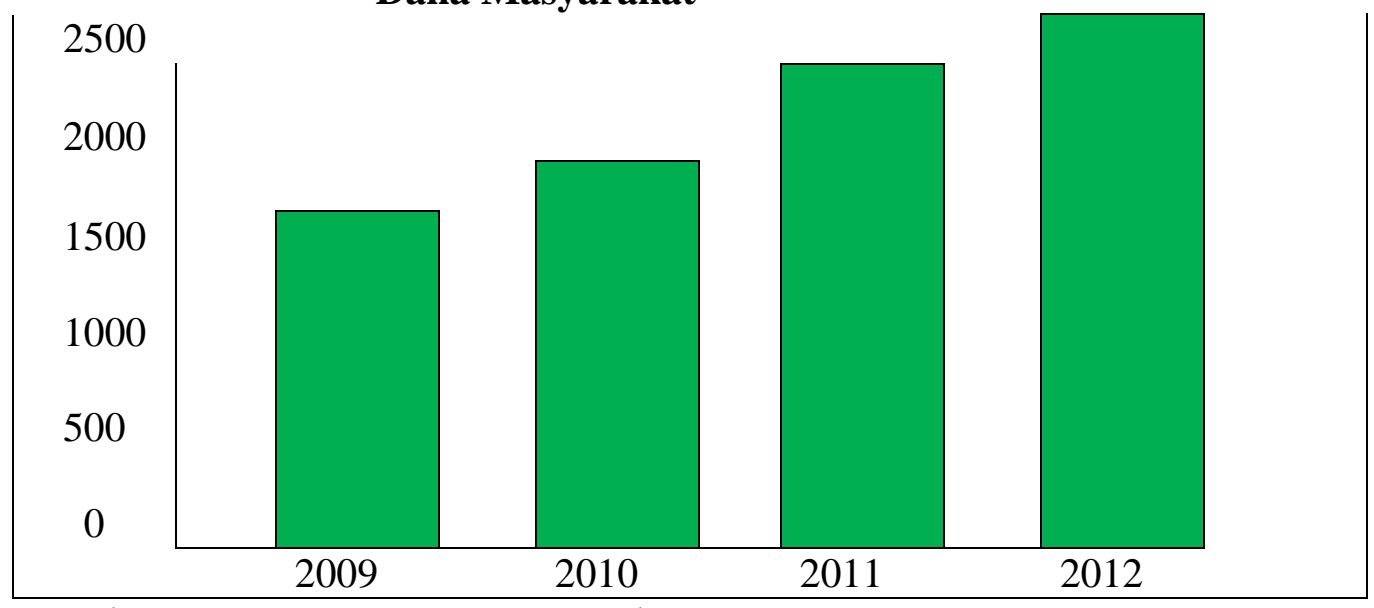

Sumber : PT. BPR LA Mangau Sejahtera Pariaman

Dana masyarakat pada akhir 2009 dana masyarakat yang dihimpun sebesar Rp. 1.592.000.000, meningkat menjadi Rp. 1.801.000.000 pada akhir Desember 2010 dan pada akhir Desember 2011 mencapai Rp. 1.821.000.000. Pada 2012 dana masyarakat meningkat menjadi Rp. 2.638.000

\section{- Penyaluran Kredit}

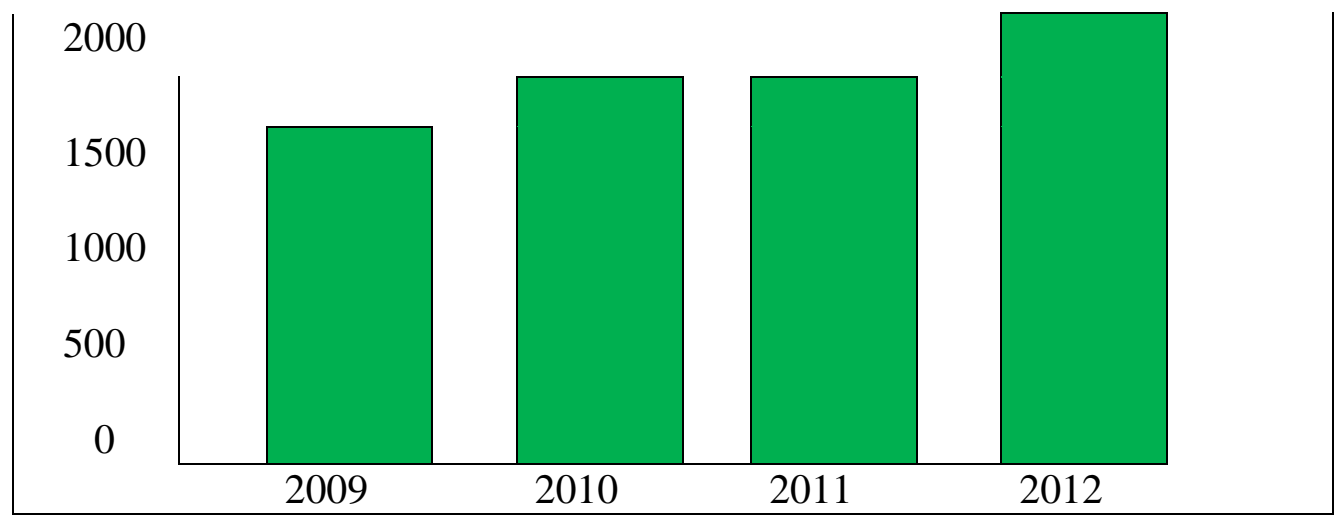

Sumber : PT. BPR LA Mangau Sejahtera Pariaman

Penyaluran kredit pada tahun 2009 sebesar Rp. 1.562.000.000, meningkat menjadi Rp. 1.600.000.000 pada 2010 dan pada akhir Desember 2011 meningkat lagi menjadi Rp. 1.665.000.000. Demikian pula pada tahun 2012 meningkat lagi menjadi Rp. 1.820.000.000. 


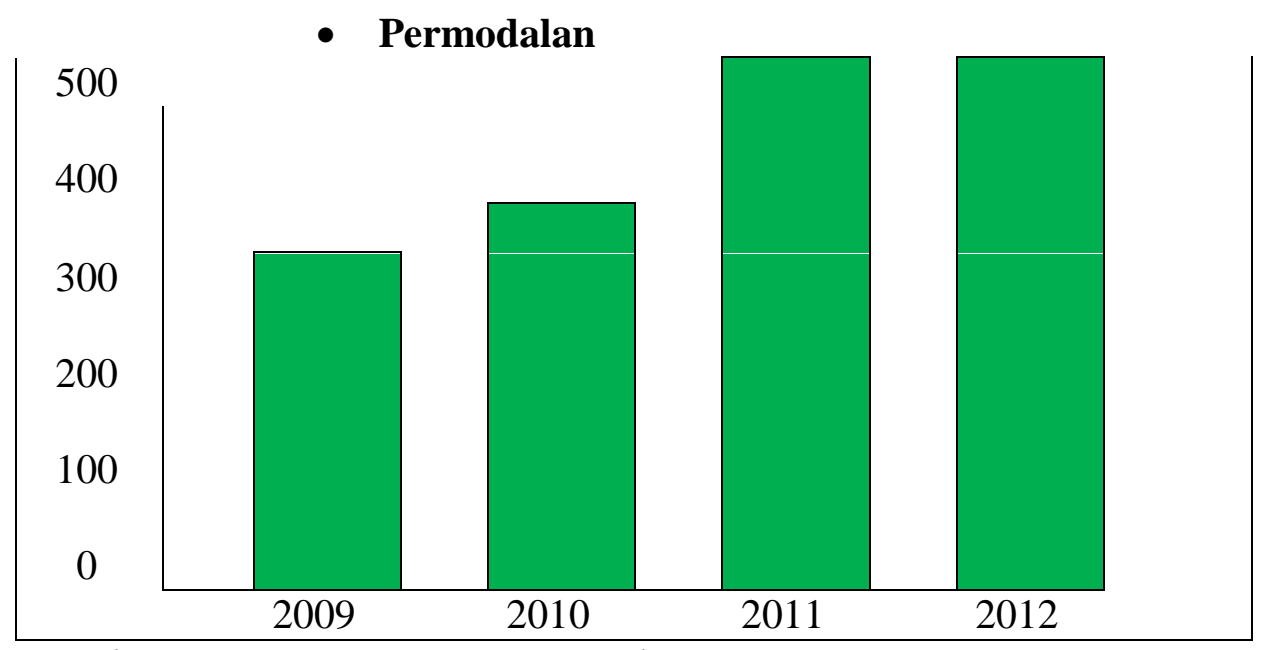

Sumber : PT. BPR LA Mangau Sejahtera Pariaman

Permodalan pada akhir Desember 2009 modal BPR Rp. 353.000.000 dan pada Desember 2010 menjadi Rp. 504.000.000 dan pada 2011 serta 2012 modal yang disetujui Bank Indonesia Rp. 504.000.000.

Dari beberapa grafik di atas dapat di simpulkan bahwa perkembangan usaha Bank Perkreditan Rakyat LA Mangau Sejahtera Pariaman dapat dilihat dari peningkatan Asset, Dana Masyarakat, Penyaluran Kredit, dan Permodalan. Dari Asset, Dana masyarakat, dan Penyaluran Kredit pada tahun 2009 - 2012 selalu mengalami peningkatan meskipun tidak signifikan, dan untuk Permodalan pada tahun 2009 - 2010 mengalami peningkatan namun pada tahun 2011 - 2012 tidak mengalami peningkatan atau tetap.

\section{Pengawasan Pemberian Kredit}

Pengawasan kredit biasanya merupakan tanggung jawab lebih dari satu departemen dalam bank. Proses analisa laporan perlu diadakan ketika kredit dibayar, setelah kredit itu diberikan dan dana diperlukan. Budged adalah alat estimasi yang sifatnya fleksibel menurut keperluan dan bank tidak bias menekan para pelanggan untuk mengikuti aktivitas-aktivitas bank secara tepat. Jangka waktu dimana laporan keuangan dijamin aman dari para debitur, tergantung pada rencana-rencana yang telah dibuat dan tergantung pada catatan akuntansinya. Salah satu yang dilakukan dalam praktek bila kredit yang beredar dalam keadaan mengkhawatirkan seperti, dengan mengarsipkan laporan-laporan keuangannya yang diperlukan dalam jangka waktu tertentu, biasanya dalam setiap bulan. Pemeliharaan laporan-laporan keuangan yang teratur dilakukan dalam departemen yang menangani masalah perkreditan dan mirip dengan bagian yang menangani aplikasi kredit yang diajukan oleh langganan.

Pengawasan yang dilakukan oleh PT. BPR LA Mangau Sejahtera Pariaman merupakan hal yang penting dalam usaha perbankan. Tujuan dari pengawasan pemberian kredit ini untuk menjaga, mengamankan dan mengantisipasi terjadinya penyimpangan yang dapat menjadikan kredit 
bermasalah dan jika tidak ditindaklanjuti akan menyebabkan kerugian bagi Bank. Serta dengan adanya sistem ini, pihak Bank dapat mengetahui dengan cepat munculnya potensi kredit bermasalah yang dapat merugikan Bank.

Adapun factor pengawasan yang mempengaruhi tingkat kesehatan bank pada PT. BPR LA Mangau Sejahtera Pariaman sebagai berikut :

a. Sistem pengawasan

Sistem pengawasaan yang diterapkan adalah pengawasan melekat melalui penetapan batasan kewenangan dalam menanda tangani surat, laporan , pembayaran dan penyaluran kredit.

b. Monitoring dan Penagihan kredit

Komisaris melihat bahwa Direksi telah berupaya dengan berbagai cara untuk menyelesaikan kredit bermasalah seperti melakukan penangihan, mengirim, surat peringatan, menarik dan menjual jaminan, meminta bantuan pihak terkait seperti polisi.

c. Hubungan kerja

Komisaris melihat bahwa hubungan kerja Komisaris dengan Direksi, Direksi dengan Karyawan dan sesama karyawan berjalan lancar.

d. Praktek atau kejadian yang tidak sehat

Berdasarkan pemantauan dan pengamatan Komisaris, tidak terlihat tidak terlihat adanya praktek-praktek yang tidak sehat yang dilakukan oleh Direksi dan atau karyawan bank dalam pemberian kredit ataupun dalam memenuhi ketentuan Batas Maksimum Pemberian Kredit (BMPK).

\section{Kredit Bermasalah dan Cara Mengatasi Kredit Bermasalah}

Kredit Bermasalah yaitu Kredit yang di dalam pelaksanaannya belum mencapai / memenuhi target yang diinginkan oleh pihak BPR, Memiliki kemungkinan timbulnya resiko dikemudiaan hari bagi BPR dalam arti luas, serta Mengalami kesulitan di dalam menyelesaikan kewajiban baik dalam bentuk pembayaran kembali pokoknya dan atau pembayaran bunga, denda keterlambatan (kondisional tergantung situasi) menjadi beban nasabah yang bersangkutan.

Faktor penyebab terjadinya kredit bermasalah pada PT. BPR LA Mangau Sejahtera Pariaman sebagai berikut :

a. Faktor Intern

- Analisa kredit atau kredit yang tidak akurat

- Lemahnya pengawasan dan monitoring

- Kredit diberikan secara terkonsentrasi baik jumlah maupaun penerimaannya

- Lemahnya SDM (Sumber Daya Manusia)

b. Faktor Ekstern

Dimana nasabah menyalahgunakan kredit yang diperolehnya

c. Faktor Kesulitan Usaha

Faktor kesulitan usaha yang diindikasikan oleh beberapa hal :

1. Indikasi Manajemen

- $\quad$ Key Person meninggal dunia

- $\quad$ Perubahan struktur manajemen yang terlalu cepat atau sering 
- $\quad$ Tidak mampu melakukan rencana bisnis

2. Indikasi Industri

- $\quad$ Mudah dimasuki industri lain

- $\quad$ Muncul persaingan baru

- $\quad$ Raw material yang terbatas

- Teknologi ketinggalan

- Tidak stabil dipasar

3. Industri Produksi

- $\quad$ Perrmintan menurun

- $\quad$ Tidak stabil dalam mutu

- Pelanggan utama menurun

- $\quad$ Kualitas dan kuantitas tidak dapat bersaing

4. Indikasi Ekonomi

- $\quad$ Krisis ekonomi atau kehidupan ekonomi sedang lesu

- Pasar local atau nasional sedang menurun

- $\quad$ Kebijakan uang ketat

- $\quad$ Pertumbuhan ekonimi rendah

Pada Bank Perkreditan Rakyat LA Mangau Sejahtera Pariaman dampak bila terjadi kredit bermasalah :

- Hilangnya kesempatan untuk memperoleh kesempatan sehingga mengurai perolehan laba dan pengaruh buruk terhadap rentabilitas BPR.

- Rasio kualitas aktiva produktif semakin besar.

- BPR harus memperbesar penyisihan untuk cadangan aktifa produktif.

- RAO (Return On Asset) mengalami penurun.

Dalam penanganan atau mengatasi kredit bermasalah PT. BPR LA Mangau Sejahtera Pariaman ada beberapa hal :

a. Tindakan Preventif

Tindakan yang bersifat Pencegah, tindakan ini bersifat Intern. Untuk itu keberhasilan dari tindakan ini sangat tergantung dari kualitas SDM (Sumber Daya Alam), system dan prosedur, mekanisme monitoring dan evaluasi. Secari garis besar tindakan preventif dapat dilakukan melalui :

- Analisis Kredit

- Mekanisme Monitoring dab Evaluasi

b. Tindakan Revitalisasi

Merupakan Tindakan dalam rangka memperbaiki dan menyelamatkan kredit atau kredit yang telah diberikan kepada nasabah. Tindakan ini dilakukan untuk kredit yang telah atau sedang memasuki wilayah "Bermasalah" .

c. Tindakan Kuratif

Merupakan Tindakan yang bersrifat penyelamatan melalui penangan yang menggunakan pendekatan aspek legal formal. 


\section{KESIMPULAN}

1. Di dalam pelaksanaannya kredit yang disalurkan oleh BPR LA Mangau Sejahtera Pariaman adalah kredit yang berdasarkan tujuan penggunaannya yang terdiri kredit modal kerja (KMK), investasi dan konsumsi. Dengan tingkat bunga kredit sebesar $13 \%$ sampai $20 \%$.

2. Faktor penyebab terjanjinya kredit bermasalah pada PT. BPR LA Mangau Sejahtera Pariaman adalah faktor intern, faktor ekstern, dan faktor kesulitan usaha, dan Penanganan atau mengatasi kredit bermasalah dengan Tindakan preventif, Tindakan revitalisasi dan Tindakan kuratif.

\section{DAFTAR PUSTAKA}

Alanshari, F., \& Marlius, D. (2018). Prosedur Pemberian Kredit KPR Pada PT. Bank Tabungan Negara (Persero) TBK Cabang Pembantu Bukittinggi. https://doi.org/10.31227/osf.io/rsfhc

Amelia, L., \& Marlius, D. (2018). Pengendalian Kredit Dalam Upaya Menciptakan Bank Yang Sehat Pada PT. Bank Pembangunan Daerah Sumatera Barat Cabang Utama Padang. https://doi.org/10.31227/osf.io/kpc64

Andriani, B., \& Susanto, R. (2019). Pengawasan Kredit PT. Bank Perkreditan Rakyat (BPR) Ophir Pasaman Barat. https://doi.org/10.31219/osf.io/aunvc

Darmawanto, \& Fernos, J. (2019). Prosedur Pemberian Kredit Pada Bank Nagari Cabang Sijunjung. https://doi.org/10.31227/osf.io/psqfy

Dendawijaya, Lukman. Manajemen Perbankan, Jakarta : Gramedia Indonesia. 2008.

Febriansyah, I., \& Afriyeni, A. (2019). Penyelesaian Kredit Bermasalah PT. Bank Pembangunan Daerah (BPD) Sumbar Cabang Alahan Panjang Kabupaten Solok. https://doi.org/10.31219/osf.io/vutmj

Ikbal, M., \& Marlius, D. (2017). Pengaruh Jumlah Taksiran Dan Uang Pinjaman Terhadap Laba Bersih Pada PT. Pegadaian (UPC) Gurun Laweh. https://doi.org/10.31227/osf.io/uch4a

Kasmir. Manajemen Perbankan, Edisi Pertama. Jakarta : PT Raja Grafindo Persada. 2000.

Orlando, A., \& Susanto, R. (2019). Mekanisme Pencairan Kredit Usaha Rakyat Pada PT. Bank Rakyat Indonesia Unit Lubuk Buaya. https://doi.org/10.31219/osf.io/zuv2y 
Pratama, D., \& Fernos, J. (2019). Prosedur Pelaksanaan Kredit Usaha Rakyat (KUR) Pada PT. Bank Nagari Cabang Padang. https://doi.org/10.31227/osf.io/ag68j

R., \& Afriyeni, A. (2019). Mekanisme Transaksi Dan Sistem Perhitungan Bunga Kredit Usaha Mikro Kecil Dan Menengah (UMKM) Pada PT. Pegadaian (Persero) Cabang Ulak Karang. https://doi.org/10.31219/osf.io/rqneu

Sinungun, Muchdarsyah Drs. Manajemen Dana Bank, Edisi Kedua. Jakarta : Bumi Aksara.1993.

Tri Cahyono, Bambang. Manajemen Perkreditan, Edisi Pertama. Yogyakarta Ananda. Juni 1983.

Thomas, Suyatno.dkk. Dasar-Dasar Perkreditan, Edisi Keempat. Jakarta : PT Gramedia. Pustaka Utama. 1995.

Tje'Aman, Edy Putra, SH. Kredit Perbankan. Yogyakarta : Liberty. Juli 1989.

Undang-Undang Republik Indonesia Nomor 7 Tahun 1992 dan Nomor 10 Tahun 1998, "Tentang Perbankan ", Sinar Grafka, Jakarta. 2002

Widayati, R. (2019). Aktivitas Pemberian Kredit Komersil Pada Bank Nagari Cabang Sijunjung. https://doi.org/10.17605/OSF.IO/QTVZ9

Widayati, R. (2019). Aktivitas Pemberian Kredit Usaha Pada PT. Bank Perkreditan Rakyat Batang Kapas. https://doi.org/10.17605/OSF.IO/EDPN4

Yasman, R., \& Afriyeni, A. (2019). Prosedur Pemberian Kredit Pada PT. Bank Pekreditan Rakyat (BPR) Jorong Kampung Tangah (JKT) Pariaman Cabang Padang. https://doi.org/10.31219/osf.io/c5ufr 